\title{
Humanitarian Communication in a Post-Truth World
}

\author{
Mel Bunce \\ Senior Lecturer in Journalism and Director of the Humanitarian News Research Network at City, University of London; \\ melanie.bunce.1@city.ac.uk
}

\begin{abstract}
When people look online for information about humanitarian crises, they increasingly encounter media content that blurs the line between reality and fiction. This includes everything from rumour and exaggeration to partisan journalism and completely invented stories designed to look like real news (so-called 'fake news'). This article shows that disinformation is causing real and serious harm to those affected by humanitarian emergencies; it can undermine the ability of humanitarian workers to provide relief; and it has exacerbated conflict and violence. Disinformation is also making it harder for journalists to report on the humanitarian sector, and hold the powerful to account, because it undermines audience trust in information more generally. The article concludes by considering interventions that could address the challenges of disinformation. It argues for more support of quality journalism about humanitarian crises, as well as media literacy training. Finally, it is crucial that aid agencies and news outlets commit to accuracy and fact checking in their reporting and campaigning.
\end{abstract}

Keywords: disinformation, fake news, humanitarian communication, international journalism, truth

In 2014, a campaign group posted a video on YouTube called 'Syrian hero boy'. The clip showed a young boy dramatically running through gunfire to save a girl, and it quickly went viral. The video was viewed more than five million times and republished on the websites of mainstream news outlets around the world, including the Daily Telegraph, Independent, Daily Mail and New York Post. It was also shared by the organisation Syria Campaign, which attached a petition calling on world leaders to stop the conflict.

There was just one problem: the video wasn't real. It was the creation of 34-year-old director Lars Klevberg, and it was filmed in Malta with child actors, using a set from the movie Gladiator. Klevberg said he wanted the video to start a conversation about the impact of war on children. Critics said he had gone too far: that the video created confusion and cynicism, which undermined attempts to address conflict in Syria (Salyer, 2014).

'Syrian hero boy' was not an isolated incident. When audiences look online for information about humanitarian crises, they increasingly encounter media content that blurs the line between reality and fiction. This includes everything from rumours and exaggerations on social media, through to partisan journalism, satire and completely invented stories that are designed to look like real news articles. Although this media content varies enormously, it is often grouped together under nebulous and all-encompassing terms such as 'fake news', 'disinformation' or 'post-truth' media.

Scholars have started to pay serious attention to the production and impact of all these forms of disinformation. But they have not yet closely examined their impact in humanitarian crises. This is a remarkable oversight. In humanitarian crises, false information can have life-anddeath consequences. As Jeanne Bourgault, President and Chief Executive Officer of Internews, states, false information can 'undercut efforts to improve health, make disasters worse than they already are, alienate vulnerable populations, and even incite violence' (quoted in Igoe, 2017).

This article introduces the emerging research about online disinformation and the many forms it can take. It then considers the impact of this disinformation on humanitarian crises, identifying a number of cases where it has caused real harm for those affected by disaster. Even more troubling, perhaps, is the impact it may have on audiences in the long term and their willingness to trust the news media when it provides important information or holds those with power to account. The article finishes by examining the groups that are

\section{MANCHESTER} 1824

Manchester University Press 
producing disinformation about humanitarian crisis and asking what can be done.

\section{F*** News and Disinformation}

In 2017, Collins Dictionary declared 'fake news' its word of the year. But most media scholars would prefer the term was removed from the English lexicon, as it is vague and can be deployed to advance a political agenda. Donald Trump famously uses the phrase 'fake news' to refer to a wide range of media content that he doesn't like. And audiences take a similarly broad approach; in focus groups, Nielsen and Graves (2017) find that audiences define 'fake news' to include partisan journalism, propaganda and advertising as well as invented stories that masquerade as news reports.

Attempting to add clarity to the debate, journalism commentator and researcher Claire Wardle (2017) suggests that we should distinguish between different types of fake news, paying attention to: 1) the nature and type of the content, 2) the motivation of the producer and 3) how it is disseminated. From this analysis, Wardle suggests there is a spectrum of fake news: at one end is satire and parody content that has no intention to cause harm but can potentially fool audiences; in the middle there is content that is taken out of context or manipulated; and at the other end is news content that is 100 per cent false and is designed to deceive (see also Tandoc et al., 2018).

None of these different types of fake news are new. The news media have long published exaggerations, false information, propaganda and conspiracy theories, presenting them as truth. In the 1830s, for example, New York Post published a series of articles claiming that life had been found on the moon (Tworek and Hamilton, 2018). Staged and fabricated content was also common during the American-Spanish war, and it continued through the 'penny press' era in the US, where duelling editors sought to grow their readership with fantastical and scandalous accounts of events (Tucher, 1994).

Although it is not new, two factors are making the challenges of disinformation far more acute today. The first is technology. The internet has led to an explosion of all information sources - both truthful and false - and the sheer quantity of sources makes it increasingly difficult to delineate the two. When the celebrated British philosopher Onora O'Neill gave the 2002 Reith lectures, she predicted these challenges to come:

It is quite clear that the very technologies that spread information so easily and efficiently are every bit as good at spreading misinformation and disinformation... [people] may not heed available evidence and can mount loud and assertive campaigns for or against one or another position whether the available evidence goes for or against their views.

(O’Neill, 2002)

It is now very cheap and easy for anyone to spread falsehoods - for a motivated individual to create a website that looks like it is a traditional news outlet or to make a false claim on social media and watch it go viral. The extent of this issue was confirmed in a recent, massive study of online information flows published in Science, which analysed the spread of approximately 126,000 ideas across millions of tweets. This analysis found that 'falsehood diffused significantly farther, faster, deeper and more broadly than truth in all categories of information' (Vosoughi et al., 2018: 1146). Other studies have shown that the most 'successful' fabricated stories can attract more likes and retweets than the most popular and accurate stories published in the mainstream media (Allcott and Gentzkow, 2017).

These findings cut to the heart of some of our most celebrated ideals about free speech and democracy. For centuries, liberal philosophers have argued that open debate and discussion will edge us closer to the truth. As John Milton proclaimed in 1644, 'Let [truth] and Falsehood grapple; whoever knew Truth put to the worse, in a free and open encounter?' Two centuries later, John Stuart Mill, perhaps the most famous advocate of free speech, made a similar argument. He suggested that if we can only stand up and freely challenge false ideas then we will see 'the clearer perception and livelier impression of truth, produced by its collision with error' (1859: 33). This central tenet is called into question by the chaos of online misinformation, channelled and amplified through social media.

A second phenomenon has made the challenge of disinformation more acute today: the behaviour of political elites. More specifically, the willingness of leaders, even those in supposedly liberal democratic states, such as the US, UK and Italy, to lie to the public or disregard evidence. Donald Trump is, of course, the most famous example of this phenomenon. According to the Washington Post fact checkers, in his first 600 days in office, President Trump made 5,001 false or misleading claims (Washington Post, 2018). This disregard for facts is said to have contributed to a wider 'post-truth' political landscape in the US - that is, a culture in which empirical evidence plays a vastly reduced role (McIntyre, 2018). In addition, Trump's attacks on the news media have created additional confusion about which information sources can be trusted (Mourão et al., 2018), and this allows disinformation and falsehoods to flourish.

\section{Disinformation and Humanitarian Crises}

There have not been any systematic studies of the quantity or reach of disinformation about humanitarian 
issues. But there are many anecdotal examples that have been documented - and there is reason to think that the phenomenon is causing real and extensive harm.

During the 2014 Ebola outbreak in West Africa, websites masquerading as news outlets published false stories about the causes and cures of the disease. In Nigeria, two people died and twenty were hospitalised after drinking excessive quantities of salt water, which they read would protect them from the disease (Neporent, 2014). In the US, multiple websites published false news stories that contained alarmist accounts, one claiming that an entire town in Texas was being quarantined after a family tested positive for the virus. The story was shared more than 300,000 times (Dzieza, 2014) and may have contributed to the wider landscape of panic and xenophobia surrounding the epidemic.

Online disinformation has also exacerbated conflict. In South Sudan, the UN reports that social media 'has been used by partisans on all sides, including some senior government officials, to exaggerate incidents, spread falsehoods and veiled threats, or post outright messages of incitement' (UN Security Council, 2016: 10). In one instance, a false news story, published on the website SouthSudanNation.com, stated that a general was planning to 'massacre Equatorians'. The story spread through WhatsApp, YouTube and Facebook as well as offline networks, and was used 'to mobilize others to take up arms to counter the "attack"' (Reeves, 2017; see also Lynch, 2017).

Finally, false news has made it more difficult for relief organisations to operate. Organisations working with migrants in the Mediterranean, for example, have been targeted in fake-news attacks (Magee, 2018). Sean Ryan, Director of Media at Save the Children, describes his organisation's experience:

In the Mediterranean our search and rescue operations have been falsely accused of colluding with traffickers. It started as a report in the Italian media and then Defend Europe, the far-right group, hired their own boat to try and stop what we were doing. Breitbart released a video which purported to prove our collusion with traffickers but showed nothing of the kind. We had to fight this propaganda without many resources...

(cited in ibid.: 8)

These allegations suck up valuable resources, not least by requiring public-relations and legal responses. More importantly, they can feed into and foster an antimigrant climate and increase mistrust towards NGOs and their interventions.

In addition to these short-term consequences, disinformation may have a profound long-term impact by undermining the trust that citizens place in all sources of information. Research shows that audiences are confused and concerned about disinformation, and they struggle to know which sources of news to trust. A 2018 Pew Centre study found that 42 per cent of Americans believe the news media 'fabricate stories frequently' (Guess et al., 2018). And America is not exceptional. The Reuters Digital News Report 2018, which surveyed more than 70,000 people around the world, found that over half (54 per cent) of respondents were concerned about their ability to distinguish real and fake information on the internet. Similarly, the 2018 Edelman Trust Barometer, which surveyed more than 30,000 people in 28 countries, found a remarkable 59 per cent support the phrase 'I am not sure what is true and what is not' (Edelman, 2018).

Among other issues, this lack of trust makes it much harder for journalists to do their job - to provide information about humanitarian issues and to hold those with power to account. The news media has historically played an important (albeit imperfect) role in supporting the response to humanitarian emergencies: by providing surveillance and early warning, raising awareness and monitoring the treatment of citizens (Cottle and Cooper, 2015: 4). If audiences do not trust the news media to provide reliable information, it can no longer perform these tasks.

Trust is also crucial in photojournalism, which has historically played a special role in humanitarian journalism and witnessing (Bunce et al., forthcoming). Early foreign correspondents, working before the camera was invented, argued that written text was unable to convey the horrors they encountered reporting on humanitarian crises (Curtis, 2015: 29). Photography helped to overcome this barrier: what Scarry has called 'pain's inexpressibility' and resistance to 'verbal objectification' (1987). During a devastating famine in India in 1876-8, a British military official took a series of photographs depicting extremely emaciated men, women and children, and these had a profound impact on the way British elites and audiences mobilised and responded to the famine (Twomey, 2015). Twomey argues that this crisis introduced the practice of displaying shocking images as 'evidence' of bodily suffering and deprivation that might prompt humanitarian action (ibid.: 52).

For a photo or video footage to 'work', however, the audience must trust its creator. As Roland Barthes argued, the reality of photographs, and their guarantee of authenticity, does not rest in the photographs themselves: 'it is lent by editors and later by viewers who accept the claims made by texts that they are proof of "what-has-been"' (Barthes, 1977: 44). The proposed contract between an event and its truthful representation was hard enough to sustain in the era of traditional, chemical photography, but it has become more difficult 
in the era of digital photography, in which editing and manipulation of photos is widespread, cheap and easy (Taylor, 2000: 132). In fact, it is strained to breaking point now photographs are frequently disembodied from their producer and sent into the world without any detail of their provenance.

Alarmingly, the technology that enables multimedia deception improves every day. Engineers and programmers have created software that can mimic voice exactly; and they are on the cusp of creating fake videos from scratch that are indistinguishable from real footage. One writer in Atlantic Magazine has gone as far as arguing that 'manipulated video will ultimately destroy faith in our strongest remaining tether to the idea of a common reality' (Foer, 2018).

\section{Who Is Making Disinformation about Humanitarian Crises?}

The creators of disinformation are motivated by multiple factors. Some seek financial gain, such as the teenagers in Macedonia who famously produced false news stories in the lead up to the 2016 US election (Silverman \& Alexander, 2016). In humanitarian crises, however, the more common driver of disinformation creation appears to be partisanship and political influence. Humanitarian emergencies are often heavily politicised and multiple stakeholders seek to influence their representation in the news media and elsewhere online. Some of these groups are willing to spend considerable resources to create fabricated websites and social media content: a continuation of long traditions of propaganda.

Russian President Vladimir Putin oversees extensive, precise, disruptive fake-information campaigns that are designed to cause confusion (Paul \& Matthews, 2016). At Russia's 'Internet Research Agency', hundreds of employees write content for false blogs and social media accounts. These are then mobilised to create disinformation campaigns about issues ranging from the conflicts in Syria and the Ukraine to an invented explosion at a chemical plant in Centerville, Louisiana (Chen, 2015). MIT media researcher Ethan Zuckerman calls this content 'disinformatyza': 'news that's not trying to persuade you ... it's trying to pollute the news ecosystem, to make it difficult or impossible to trust anything. ... Disinformatyza helps reduce trust in institutions of all sorts, leading people either to disengage with politics as a whole or to put their trust in strong leaders who promise to rise above the sound and fury' (2017).

In 2018, extensive disinformation campaigns were traced back to Iran, too. More than 600 Facebook pages and 300 Twitter accounts linked to the Iranian regime were shut down for their involvement in a concerted campaign (Gilbert, 2018). According to FireEye, the security firm that discovered the campaign, these accounts were a coordinated operation that leveraged 'a network of inauthentic news sites and clusters of associated accounts across multiple social media platforms to promote political narratives in line with Iranian interests' (ibid., 2018), including of the IsraelPalestine conflict, politics in North Korea and the UK's departure from the EU.

In Syria, there is a fervent propaganda war between the Americans, Russians and Iranians, and between rebel and regime groups. All are extremely active online. Proregime Russian content producers have created websites and attacked groups like the White Helmets, calling them 'terrorists' and dismissing stories about children killed by chemical attacks as fake news featuring 'actors' (Solon, 2017). In articles from all sides of the campaign, there are links to official-looking reports and the biographies of experts that seem trustworthy. It can be very difficult to discern the provenance of information or the agenda of a source (Hayden, 2018: 15).

NGOs are not passive bystanders in this (dis)information landscape. They too engage in strategic information campaigns and can mislead audiences with their content. A prominent example in the 2000s was the Save Darfur Coalition, which used inflated mortality statistics to raise awareness of the conflict in Darfur. These exaggerated claims were reproduced by many news outlets in their reports of the conflict. The group also took out full-page newspaper adverts alleging that Sudanese President, Omar al-Bashir, had overseen the killing of 400,000 citizens in Darfur - double the 200,000 deaths estimated by other experts (de Waal, 2007). The adverts were ultimately ruled misleading by the British Advertising Standards Authority; this was an embarrassing outcome that played directly into the hands of the Sudanese government and its allegations that Western groups were exaggerating the scale of the conflict (Mamdani, 2007).

In addition to their own campaign content, NGOs consistently and actively seek to influence journalists and their representations of crises. This has included exaggeration of the scale of crises and the simplification - or omission - of their root causes; it has also included 'media stunts' deigned to capture the media spotlight. In her book Who's Reporting Africa Now? (2018), Kate Wright documents how NGOs create content and stage events that can mislead journalists, resulting in significant, and false, news coverage (see also Franks, 2008; Cottle and Nolan, 2007).

In an ideal world, journalists would fact-check and verify all such claims before they published them. In practice, however, news organisations are often too 
rushed to do this, and even the most well-regarded and trusted outlets reproduce NGO and publicity content. Nick Davies documents this phenomenon in his book Flat Earth News (2008), showing that vast quantities of 'churnalism' fill the pages of the UK press. Working under intense resourcing pressures and required to churn out tens of articles a day, journalists look online for existing content - press releases, marketing material, social media posts and previously published news articles and newswire articles - and they frequently republish this content with only slight amendments.

International news desks are under particularly intense pressures. There have been deep cuts to the number of foreign correspondents around the world over the last twenty years (Sambrook, 2010). Today, the vast majority of news outlets around the world do not have foreign correspondents of their own. And if they do include international news in their media packages, it is by repurposing content produced by others (Scott et al., 2018). The most common sources for this content are international newswires, such as Thomson Reuters and AFP. This is not necessarily problematic: newswires place a very high premium on accuracy and verification of sources. But news outlets may also rely heavily on NGO content or material discovered on social media - as was the case with 'Syria hero boy', mentioned in the introduction. And this does raise the likelihood that unverified or false information will be further disseminated.

\section{What Can Be Done?}

Facebook, YouTube, Google, Twitter, WhatsApp and other media platforms are all under increasing pressure to prevent harmful disinformation from circulating on their platforms. It is vital that these massive organisations start to tackle the problem. But there are also steps that researchers, journalists and humanitarians can take.

The first priority is further research. Although fake news has dominated public debate, conference programming and presidential tweets for some time, we have relatively little empirical data about its reach or impact. A number of countries have decided to introduce new laws without this evidence base to stifle what they define as fake news. The Malaysian government, for example, introduced legislation banning 'news, information, data and reports which is or are wholly or partly false'. India, the UK and France are among other countries considering laws for misinformation. Paul Bernal, a legal researcher argues that the 'fake news crisis' is a straw man, an excuse for governments that have wanted to shut down certain types of debate for some time: 'the fake news saga... provides an opening for them to do this. It's a Trojan horse' (quoted in Priday, 2018).
The second priority is securing more stable funding for humanitarian journalism. This includes, crucially, trustworthy information reaching those communities affected by disaster. Following the work of organisations including the CDAC Network, Internews and BBC Media Action, we know that this is a vital form of aid: people need information as they need water, food, medicine and shelter. Information can save lives, build resilience, support livelihoods and empower (Hannides, 2015: 9). Information provision should be prioritised within all humanitarian responses. In addition, international journalism about humanitarian disasters needs financial support. This content is incredibly important but rarely profitable, and so it is neglected by the commercial news market. This means it is vital that citizens, foundations, philanthropists and publicservice outlets value and support this work (Scott et al., 2018).

The third priority is media literacy. We need audiences to know how to distinguish sources that are trustworthy from those that are not. Education strategies will play a crucial role in the global response to disinformation. Legislators in California are currently considering a bill that would embed more media literacy into the curriculum as well as provide media-literacy training for teachers (California News Publishers Association, 2018). Meanwhile, the European Commission's High Level Group for misinformation and fake news has made a key recommendation that member countries 'promote media and information literacy to counter disinformation and help users navigate the digital media environment' (European Commission, 2018).

More broadly, we need to focus curricula on critical thinking and reasoning. Recent interventions have shown this can be massively beneficial to students' ability to discern opinion and anecdote from scientific evidence. In 2016, researchers ran a huge trial involving 10,000 schoolchildren in 120 primary schools in Kampala, Uganda. The results, recently published in The Lancet (Semakula et al., 2017), show that children who were taught basic concepts about critical thinking vastly outperformed the control group at a series of scenariobased tests. They were more likely to reject arguments based on anecdote and raise doubts about health cures that had not been scientifically tested.

Finally, news outlets and NGOs need to commit to accurate reporting and campaigning. There can be a strong temptation for journalists and communication teams to provide exaggerated or sensationalist accounts. This content can come from a good place - it reflects a utilitarian ethic in which the outcome (more funds/ awareness/action) is seen to justify the means (exaggeration or fabrication). But exaggerated content can create serious, long-term damage that far outweighs these 
short-term gains. It can make it harder for humanitarian groups to respond to crises; it can cause confusion that leads audiences to 'turn off, not knowing who to trust; and it can play directly into the hands of those who would discredit journalists and activists.

It is not clear exactly how online technologies will evolve and reshape humanitarian communications in the future. But we know that, in our new information ecology, trust is more vital than ever before. We must support media institutions and citizens as they seek out trustworthy sources.

\section{Bibliography}

Allcott, H. and Gentzkow, M. (2017), 'Social Media and Fake News in the 2016 Election', Journal of Economic Perspectives, 31:2, 211-36.

Aly, H. (2017), 'Media Perspectives: A Means to an End? Creating a Market for Humanitarian News from Africa', in Bunce, M., Franks, S. and Paterson, C. (eds), Africa's Media Image in the 21st Century: From the 'Heart of Darkness' to 'Africa Rising' (London: Routledge), pp. 129-31.

Barthes, R. (1977), Image/Music/Text (New York: Hill and Wang).

Bunce, M., Scott, M. and Wright, K. (forthcoming), 'Humanitarian Journalism', Oxford Research Encyclopedia of Journalism Studies (Oxford: Oxford University Press).

California News Publishers Association, (2018), 'Quashing Fake News with Media Literacy', https://cnpa.com/quashing-fake-news-withmedia-literacy/ (accessed 14 June 2018).

Chen, A. (2015), 'The Agency', New York Times, 2 June, https://www. nytimes.com/2015/06/07/magazine/the-agency.html (September 4, 2018).

Cook, J., Lewandowsky, S. and Ecker, U. (2017), 'Neutralizing Misinformation through Inoculation: Exposing Misleading Argumentation Techniques Reduces Their Influence', PLoS ONE, $12: 5,1-21$.

Cooper, G. (2007), 'Anyone Here Survived a Wave, Speak English and Got a Mobile? Aid Agencies, the Media and Reporting Disasters since the Tsunami', 14th Guardian Lecture, Nuffield College, University of Oxford.

Cottle, S. and Cooper, G. (eds) (2015), Humanitarianism, Communications and Change (New York: Peter Lang).

Cottle, S. and Nolan, D. (2007), 'Global Humanitarianism and the Changing Aid-Media Field: Everyone Was Dying for Footage', Journalism Studies 8:6, 862-78.

Curtis, H. (2015), 'Picturing Pain Evangelicals and the Politics of Pictorial Humanitarianism in an Imperial Age', in Fehrenbach, H. and Rodongo, D. (eds), Humanitarian Photography: A History (Cambridge: Cambridge University Press), pp. 22-46.

Davies, N. (2008), Flat Earth News (London: Vintage Books).

de Waal, A. (2007), 'Deaths in Darfur: Keeping Ourselves Honest', African Arguments, 16 August, http://africanarguments.org/2007/08/ 16/deaths-in-darfur-keeping-ourselves-honest/ (accessed 2 September 2018).

Dzieza, J. (2014), 'Fake News Sites Are Using Facebook to Spread Ebola Panic: They Call Themselves Satire Sites, but They're Really Spreading Scary Rumors for Profit', The Verge, 22 October, https://www.theverge. com/2014/10/22/7028983/fake-news-sites-are-using-facebook-to-spreadebola-panic (accessed 8 August 2018).

Edelman (2018) 2018 Edelman Trust Barometer Global Report, https:// www.edelman.com/sites/g/files/aatuss191/files/2018-10/2018_Edelman_Trust_Barometer_Global_Report_FEB.pdf (accessed 30 September 2018).
European Commission (2018), 'Final Report of the High Level Expert Group on Fake News and Online Disinformation', 12 March, https:/ec. europa.eu/digital-single-market/en/news/final-report-high-level-expertgroup-fake-news-and-online-disinformation (accessed 15 June 2018).

Fahy, D. (2017), 'Objectivity, False Balance, and Advocacy in News Coverage of Climate Change', Oxford Research Encylopedia of Climate Science (Oxford: Oxford University Press).

Foer, F. (2018), 'Reality's End', The Atlantic, May 2018.

Franks, S. (2008), 'Getting into Bed with Charity', British Journalism Review 19:3, 27-32.

Gilbert, D. (2018), 'Iran Is Running an Online Disinformation Campaign on the Scale of Russia's Troll Farm', Vice, 22 August 22, https://news.vice.com/en_ca/article/594ekk/iran-russia-facebooktwitter-disinformation (accessed 28 September 2018).

Goldman, R. (2016), 'Reading Fake News, Pakistani Minister Directs Nuclear Threat at Israel', New York Times, www.nytimes.com/2016/ 12/24/world/asia/pakistan-israel-khawaja-asif-fake-news-nuclear.html? _ $\mathrm{r}=0$ (accessed 8 August 2018).

Guess, A., Nyhan, B. and Reifler, J. (2018), 'All Media Trust Is Local? Findings from the 2018 Poynter Media Trust Survey', wwwpersonal.umich.edu/ bnyhan/media-trust-report-2018.pdf (accessed 30 September 2018).

Hamilton, J. and Jenner, E. (2004), 'Redefining Foreign Correspondence' Journalism 5, 3 pp. 301-21.

Hannides, T. (2015), Humanitarian Broadcasting in Emergencies: A Synthesis of Evaluation Findings, Research Report, 7, October (London: BBC Media Action).

Harsin, J. (2015), 'Regimes of Posttruth, Postpolitics, and Attention Economies', Communication, Culture \& Critique, 8:2, 327-33.

Harvey, J. et al. (2017), 'Internet Blogs, Polar Bears, and ClimateChange Denial by Proxy', BioScience, 68:4, 281-7.

Hayden, S. (2018), 'Tourist Trap', Newsweek, 13 April.

Head, J. (2017), 'Myanmar Conflict: Fake Photos Inflame Tension', $B B C$ News, www.bbc.com/news/world-asia-41123878 (accessed 8 August 2018).

Igoe, M. (2017), 'Q\&A: Fighting "Fake News" to Aid Development', Devex, 3 July, www.devex.com/news/q-a-fighting-fake-news-to-aiddevelopment-90585 (accessed 20 July 2018).

Kahn-Harris, K. (2018), 'Denialism: What Drives People to Reject the Truth', Guardian, 3 August, www.theguardian.com/news/2018/aug/ 03/denialism-what-drives-people-to-reject-the-truth (accessed 6 September 2018).

Larson, H. and Piot, P. (2018), 'Fake News and Distrust of Science Could Lead to Global Epidemics', Wired, 9 January, www.wired.co.uk/article/ how-fake-news-could-lead-to-epidemics (accessed 8 August 2018).

Lynch, J. (2017), 'In South Sudan, Fake News Has Deadly Consequences: Misinformation Can Fuel Bloodshed', Slate, 9 June, www. slate.com/articles/technology/future_tense/2017/06/in_south_sudan_ fake_news_has_deadly_consequences.html?via=gdpr-consent (accessed August 5, 2018).

Magee, H. (2018), Faking It: Fake News and How It Impacts the Charity Sector (London: International Broadcasting Trust).

Mamdani, M. (2007), 'The Politics of Naming: Genocide, Civil War, Insurgency', London Review of Books, 29:5, 5-8.

McIntyre, L. (2018), Post-Truth (Cambridge, MA: MIT Press).

Mill, J. S. (1859), On Liberty (London: Penguin Classics, 1974).

Milton, J. (1644), Areopagitica: A Speech of Mr. John Milton for the Liberty of Unlicenc'd Printing, to the Parlament of England (London).

Mourão, R., Thorson, E., Chen, M. and Tham, S. (2018), 'Media Repertoires and News Trust during the Early Trump Administration', Journalism Studies, 19:13, 1945-56.

Neporent, L. (2014), 'Nigerian Ebola Hoax Results in Two Deaths', ABC News, https://abcnews.go.com/Health/nigerian-ebola-hoaxresults-deaths/story?id=25842191 (accessed 8 August 2018). 
Nielsen, R. and Graves, L. (2017), “News You Don't Believe": Audience Perspectives on Fake News', Reuters Institute for the Study of Journalism, Factsheet, October.

Norris, P. (2000), A Virtuous Circle: Political Communications in Postindustrial Societies (Cambridge: Cambridge University Press).

Nossiter, A. (2014), 'Fear of Ebola Breeds a Terror of Physicians', New York Times, 27 July, www.nytimes.com/2014/07/28/world/africa/ ebola-epidemic-west-africa-guinea.html (accessed 1 August 2018).

Nothias, T. (2013), “It's Struck a Chord We Have Never Managed to Strike": Frames, Perspectives and Remediation Strategies in the International News Coverage of Kony 2012', Ecquid Novi: African Journalism Studies, 34:1, 123-9.

Nyhan, B. and Reifler, J. (2010), 'When Corrections Fail: The Persistence of Political Misperceptions', Political Behavior, 32:2, 303-30.

O'Neill, O. (2002), 'A Question of Trust', The Reith Lectures, BBC, www.bbc.co.uk/programmes/p00ghvd8 (accessed 8 June 2018).

Pantti, M., Wahl-Jorgensen, K. and Cottle, S. (2012), Disasters and the Media (New York: Peter Lang).

Patkin, J. (2018), 'How to Use Facebook and Fake News to Get People to Murder Each Other', Buzzfeed News, www.buzzfeednews.com/ article/jasonpatinkin/how-to-get-people-to-murder-each-otherthrough-fake-news-and\#.cqzx1Oq8KK (accessed 5 August 2018).

Paul, C. and Matthews, M. (2016), The Russian 'Firehose of Falsehood' Propaganda Model: Why It Might Work and Options to Counter It (Santa Monica, CA: Rand Corporation).

Peters, P. (2016), 'Wielding Claims of "Fake News," Conservatives Take Aim at Mainstream Media', New York Times, 25 December, www. nytimes.com/2016/12/25/us/politics/fake-news-claims-conservativesmainstream-media-html (accessed 10 June 2018).

Priday, R. (2018), 'Fake News Laws Are Threatening Free Speech on a Global Scale', Wired, 5 April, www.wired.co.uk/article/malaysia-fakenews-law-uk-india-free-speech (accessed 29 March 2018).

Reeves, B. (2017), 'Online Fake News and Hate Speech Are Fuelling Tribal "Genocide" in South Sudan', GlobalPost, 25 April.

Salyer, K. (2014), "'Syrian Hero Boy" Is a Fake, and It Matters What Happens When People Manipulate Truth to Advance a Good Cause?', Bloomberg, 15 November, www.bloomberg.com/view/ articles/2014-11-15/syrian-hero-boy-is-a-fake-and-it-matters (accessed 9 August 2018).

Sambrook, R. (2010), Are Foreign Correspondents Redundant? (Oxford: Reuters).

Sarman, S. (2014), 'Fighting the Endless Spread of Ebola Misinformation on Social Media', Fast Company, 19 August, www.fastcompany.com/3034380/fighting-the-endless-spread-of-ebola-misinformation-on-social-media (accessed 2 August 2018).

Scarry, E. (1987), The Body in Pain: The Making and Unmaking of the World (Oxford: Oxford University Press).

Scott, M., Bunce, M. and Wright, K. (forthcoming), 'The Politics of Humanitarian Journalism', in Chouliaraki, L. and Vestergaard, A. (eds), Handbook of Humanitarian Communication (London: Routledge).

Scott, M., Wright, K. and Bunce, M. (2018), The State of Humanitarian Journalism (Norwich: University of East Anglia), http://humanitarian-journalism.net (accessed 28 September 2018).

Semakula, D. et al. (2017), 'Effects of the Informed Health Choices Podcast on the Ability of Parents of Primary School Children in
Uganda to Assess Claims about Treatment Effects: A Randomised Controlled Trial', Lancet, 390:10092, 389-98, 22 July.

Silverman, C. and Alexander, L. (2016), 'How Teens in the Balkans Are Duping Trump Supporters with Fake News', Buzzfeed, 3 November, www.buzzfeednews.com/article/craigsilverman/how-macedoniabecame-a-global-hub-for-pro-trump-misinfo (accessed 3 October 2018).

Solon, O. (2017), 'Syria's White Helmets Became Victims of an Online Propaganda Machine', Guardian, 18 December, www.theguardian. $\mathrm{com} /$ world/2017/dec/18/syria-white-helmets-conspiracy-theories (accessed 20 March 2019).

Swift, A. (2016), 'Americans' Trust in Mass Media Sinks to New Low', Gallup, 14 September, http://news.gallup.com/poll/195542/americans-trust-mass-media-sinks-new-low.aspx (accessed 9 June 2018).

Tabatabai, A. (2018), 'A Brief History of Iranian Fake News: How Disinformation Campaigns Shaped the Islamic Republic', Foreign Affairs, 24 August, www.foreignaffairs.com/articles/middle-east/ 2018-08-24/brief-history-iranian-fake-news (accessed September 28, 2018).

Tandoc, E., Lim, Z. W. and Ling, R. (2018), 'Defining "Fake News"', Digital Journalism, 6:2, 137-53.

Taylor, J. (2000), 'Problems in Photojournalism: Realism, the Nature of News and the Humanitarian Narrative', Journalism Studies, 1:1, 12943.

Tucher, A. (1994), Froth and Scum: Truth, Beauty, Goodness, and the Ax Murder in America's First Mass Medium (Chapel Hill, NC: University of North Carolina Press).

Twomey, C. (2015), 'Framing Atrocity', in Fehrenbach, H. and Rodogno, D. (eds), Humanitarian Photography: A History (Cambridge: Cambridge University Press), pp. 47-63.

Tworek, H. and Hamilton, J. M. (2018), 'Why the Golden Age of Newspapers Was the Exception Not the Rule', Nieman Lab, 2 May, www.niemanlab.org/2018/05/why-the-golden-age-of-newspaperswas-the-exception-not-the-rule/ (accessed 2 September 2018).

UN Security Council (2016), Interim Report of the Panel of Experts on South Sudan Established Pursuant to Security Council Resolution 2206, www.un.org/ga/search/view_doc.asp?symbol=S/2016/963 (accessed 5 August 2018)

Vosoughi, S., Roy, D. and Aral, S. (2018), 'The Spread of True and False News Online', Science, 9 March.

Wardle, C. (2017), 'Fake News: It's Complicated', First Draft News, 16 February, https://firstdraftnews.org/fake-news-complicated/ (accessed 10 June 2018).

Washington Post (2018), 'In 601 Days, President Trump Has Made 5,001 False or Misleading Claims', Factchecker page, updated 12 September, www.washingtonpost.com/graphics/politics/trump-claims-database/? utm_term $=.1 \mathrm{c} 52 \mathrm{~b} 19325 \mathrm{a} 6$ (accessed 3 October 2018).

Wineburg, S., McGrew, S., Breakstone, J. and Ortega, T. (2016), 'Evaluating Information: The Cornerstone of Civic Online Reasoning', Stanford Digital Repository, http://purl.stanford.edu/ fv751yt5934 (accessed 30 September 2018).

Wright, K. (2018), Who Is Reporting Africa Now? (New York: Peter Lang).

Zuckerman, E. (2017), 'Fake News is a Red Herring', Deutsche Welle, 25 January, www.dw.com/en/fake-news-is-a-red-herring/a-37269377 (accessed 22 May 2018). 